\title{
Coupling between the respiratory chain and the luminescent system of Vibrio harveyi
}

\author{
Minoru Wada, ${ }^{*}$ Kazuhiro Kogure, Kouichi OhWada and Usio Simidu $\dagger$ \\ Ocean Research Institute, University of Tokyo, Minamidai, Nakano-ku, Tokyo 164, Japan
}

(Received 30 December 1991; revised 18 March 1992; accepted 15 April 1992)

\begin{abstract}
Effects of monovalent cations on luminescence and respiratory activity were studied in the marine luminous bacterium Vibrio harveyi. Maximum oxygen uptake was observed in the presence of $\mathrm{Na}^{+}$over the pH range tested (6.5-8.5). At alkaline pH, effects of monovalent cation on luminescence were similar to those on the oxygen uptake. Although $\mathrm{KCN}$ addition caused a marked increase in luminescence, the enhanced luminescence with $\mathrm{Na}^{+}$ was still greater than that with $\mathrm{Li}^{+}$. However, at acidic $\mathrm{pH}, \mathrm{K}^{+}$increases luminescence more than $\mathrm{Na}^{+}$does. These results indicate that there is not only a competitive but also a cooperative relationship between luminescence and respiration. The respiratory NADH oxidase in the membrane fraction of $V$. harveyi showed some distinctive characters which are unique to the respiratory-dependent primary $\mathrm{Na}^{+}$pump, suggesting the possibility of coupling between the $\mathrm{Na}^{+}$pump and the luciferase system. This was also supported by the results from $\mathrm{CCCP}$-resistant growth and luminescence at alkaline pH. The coupling mechanisms between luminescence and respiration in $V$. harveyi are discussed.
\end{abstract}

\section{Introduction}

Luminescent bacteria are isolated mainly from marine environments, i.e. seawater and animals in the ocean. Most of them are classified into two major genera: Vibrio and Photobacterium (Nealson \& Hastings, 1979; Baumann et al., 1983).

Detailed biochemical studies have been conducted on the luminescent systems in Vibrio fisheri, V. harveyi and Photobacterium phosphoreum (Hastings \& Nealson, 1977; Nealson \& Hastings, 1979; Meighen, 1988, 1991). The luminescent reaction which is catalysed by luciferase involves the oxidation of $\mathrm{FMNH}_{2}$ and a long-chain aldehyde. Since NADH is necessary for reduction of flavin mononucleotide, the luciferase pathway can be viewed as a branch of the electron transport system in which electrons are shunted to oxygen. Although several studies (Nealson et al., 1970; Watanabe et al., 1975; Hastings et al., 1977; Ulitzur et al., 1981; Grogan, 1984) have suggested that the luminescent system is a competitive bypass of the respiratory chain, precise

* Author for correspondence. Tel. 033376 1251; fax 0333756716.

$\uparrow$ Present address: Faculty of Applied Biological Science, Hiroshima University, Higashihiroshima 724, Hiroshima, Japan.

Abbreviations: HQNO, 2-heptyl-4-hydroxyquinoline- $\mathrm{N}$-oxide; $\mathrm{CCCP}$, carbonylcyanide- $m$-chlorophenyl hydrazone. coupling mechanisms between luminescent and respiratory systems are still unknown.

The occurrence of a novel respiratory chain was recently found in the moderately halophilic bacterium Vibrio alginolyticus (Tokuda \& Unemoto, 1981, 1982). This respiratory chain translocates sodium ions from inside to outside the cells at alkaline $\mathrm{pH}$, as a direct result of electron transport. Instead of a proton-motive force, this bacterium is able to use the sodium-motive force for various cellular functions. A similar respiratory chain has also been found in other marine bacteria (Kogure \& Tokuda, 1986, 1989; Tokuda \& Unemoto, 1983; Tokuda \& Kogure, 1989). However, to our knowledge, the coupling between luminescence and the $\mathrm{Na}^{+}$-dependent respiratory chain has not yet been investigated. The purpose of this work is to clarify the possible relationship between the two.

\section{Methods}

Bacterial strain and growth conditions. Vibrio harveyi (ATCC 14126) was grown aerobically at $20^{\circ} \mathrm{C}$ in PYG medium, which contained $0.3 \mathrm{M}-\mathrm{NaCl}, 50 \mathrm{~mm}-\mathrm{MgSO}_{4} .7 \mathrm{H}_{2} \mathrm{O}, 10 \mathrm{~mm}-\mathrm{CaCl}_{2} .2 \mathrm{H}_{2} \mathrm{O}, 10 \mathrm{~mm}-\mathrm{KCl}$, $0.5 \%$ Polypepton (Nihon Pharmaceutical), $0.1 \%$ Yeast extract (Difco) and $0.3 \%$ glycerol in deionized water. The $\mathrm{pH}$ was adjusted to 8.5 with $50 \mathrm{mM}$-Tricine/ $\mathrm{NaOH}$. The growth of $V$. harveyi was monitored as $\mathrm{OD}_{600}$ with a Hitachi Model 101 spectrophotometer. 
Preparation of cell suspension. The culture of $V$. harveyi was harvested at late-exponential phase $(\mathrm{OD}=1.0)$ by centrifugation and washed twice with salt buffer at $\mathrm{pH} 6 \cdot 5-8 \cdot 5$. The buffer contained $25 \mathrm{~mm}$-Tris/ $\mathrm{HCl}, 30 \mathrm{mM}-\mathrm{MgSO}_{4} .7 \mathrm{H}_{2} \mathrm{O}$, and $0.3 \mathrm{M}$-monovalent cation $\left(\mathrm{Li}^{+}, \mathrm{Na}^{+}\right.$, $\mathrm{K}^{+}, \mathrm{Rb}^{+}$), added as chlorides. The cell suspension, which contained about $0.3 \mathrm{mg}$ protein per $\mathrm{ml}$, was kept on ice until the measurement of luminescence and rate of oxygen consumption.

Measurement of luminescence. Luminescence of the cell suspension was measured with an ATP photometer (SAI Technology Model 3000). The suspension $(100$ or $500 \mu \mathrm{l})$ was taken into a glass vial and kept at $25^{\circ} \mathrm{C}$. After 5 min measurement of luminescent intensity was initiated. The suspension was rapidly mixed just before each measurement. Luminescence was measured for $6 \mathrm{~s}$ and the peak value was monitored. Light intensity was expressed in count units of the photometer per mg cell protein or optical cell density. Luminescence was determined from duplicate assays.

Measurement of oxygen consumption rate. The rate of oxygen consumption was determined at $25^{\circ} \mathrm{C}$ with an oxygen electrode (Rank Brothers) attached to a CU-228 recorder (Tokyo Riko). The measurement was started by the addition of $20 \mu \mathrm{l}$ cell suspension to $2 \mathrm{ml}$ airsaturated buffer. The final cell concentration was the same as those for luminescence measurement. The oxygen consumption rate was determined from duplicate assays.

Preparation of cell membrane fraction. Cells were harvested at lateexponential growth phase. Membrane fractions were prepared by the osmotic lysis method (Tokuda, 1986). The membrane fraction samples were kept below $-70^{\circ} \mathrm{C}$ until NADH oxidase assay.

Assay for NADH oxidase. NADH oxidase activity in the cell membrane fraction was determined at $25^{\circ} \mathrm{C}$ from the decrease in $A_{340}$ (Tokuda \& Unemoto, 1984). The standard assay mixture contained $20 \mathrm{~mm}$-Tris/HCl, $0.3 \mathrm{M}-\mathrm{NaCl}, 0.2 \mathrm{~mm}-\mathrm{NADH}$ and about $20 \mu \mathrm{g} \mathrm{mem}-$ brane protein in a final volume of $1 \mathrm{ml}$. The assay was started by addition of the membrane to the buffer. The rate of decrease of $A_{340}$ was followed using a Hitachi U-3200 spectrophotometer. The effect of monovalent cations $\left(\mathrm{Li}^{+}, \mathrm{Na}^{+}, \mathrm{K}^{+}, \mathrm{Rb}^{+}\right), \mathrm{pH}$ and $\mathrm{HQNO}$ (2-heptyl-4hydroxyquinoline- $N$-oxide) on the oxidase activity was observed. For calculation of the NADH oxidase activity, a value of 6.22 was used as the millimolar absorption coefficient. Activity of the oxidase was determined from duplicate assays. Deviations for most data shown were $<0.01 \mu \mathrm{mol} \mathrm{NADH} \min ^{-1}(\mathrm{mg} \text { protein })^{-1}$.

Growth and luminescence in the presence of a proton conductor. Bacterial cells were aerobically precultured in the PYG medium (pH 6.5 and 8.5 ) at $20^{\circ} \mathrm{C}$. Cells in late-exponential phase were transferred into $5 \mathrm{ml}$ fresh medium and incubated under the same conditions until the $\mathrm{OD}_{600}$ reached about $0 \cdot 1$. Then the protonconductor CCCP (carbonylcyanide- $m$-chlorophenyl hydrazone), was added to give a final concentration of $10 \mu \mathrm{M}$. Growth and luminescence of cells were monitored as was described above. The medium $\mathrm{pH}$ was constant during the cultivation.

Protein concentration. Protein was determined by the Lowry method, using bovine serum albumin as a standard.

\section{Results}

\section{Effect of monovalent cations on luminescence and respiratory activity}

Both luminescent intensity and rate of oxygen consumption varied with the monovalent cation present. As
Table 1. Effect of monovalent cations on oxygen consumption rate and luminescence of $V$. harveyi

Data shown are means \pm standard deviations.

\begin{tabular}{ccc}
\hline $\begin{array}{c}\text { Monovalent cation } \\
(0 \cdot 3 \mathrm{M})\end{array}$ & $\begin{array}{c}\mathrm{O}_{2} \text { uptake rate* } \\
\text { [nmol } \mathrm{O}_{2} \text { min }^{-1} \\
(\mathrm{mg} \text { protein })^{-1} \text { ] }\end{array}$ & $\begin{array}{c}\text { Luminescence } \\
\text { [count units } \\
(\text { mg protein) }\end{array}$ \\
\hline $\mathrm{Li}^{+}$ & $49 \cdot 7 \pm 5 \cdot 2$ & $19193 \pm 1577$ \\
$\mathrm{Na}^{+}$ & $69 \cdot 7 \pm 10 \cdot 4$ & $32148 \pm 4400$ \\
$\mathrm{~K}^{+}$ & $29 \cdot 2 \pm 9 \cdot 3$ & $8115 \pm 1100$ \\
$\mathrm{Rb}^{+}$ & $7 \cdot 1 \pm 3 \cdot 0$ & $697 \pm 198$ \\
\hline
\end{tabular}

* Oxygen consumption rate at $\mathrm{pH} 6.5$.

$\dagger$ Luminescence at pH 8.5 measured after 5 min pre-incubation.

shown in Table 1, maximal oxygen consumption occurred in the presence of $\mathrm{Na}^{+}$. The order of the monovalent cations was the same within the $\mathrm{pH}$ range (6.5-8.5) tested (data not shown).

The effects of monovalent cations on the luminescence in alkaline conditions were similar to those exerted on the oxygen consumption (Table 1). V. harveyi showed maximum luminescence in the presence of $\mathrm{Na}^{+}$at pH 8.5. However, at acidic $\mathrm{pH}, \mathrm{K}^{+}$increased luminescence more (data not shown). While $\mathrm{Na}^{+}$had a fairly constant effect on luminescence regardless of $\mathrm{pH}$, the effect of $\mathrm{K}^{+}$was $\mathrm{pH}$-sensitive; luminescent intensity at pH 6.5 was usually more than 5 times greater than that at $\mathrm{pH} 8 \cdot 5$.

The effects of cyanide addition on luminescence at pH 8.5 are shown in Fig. 1. Increased luminescence was observed in the presence of $\mathrm{Na}^{+}$or $\mathrm{Li}^{+}$, and decreased luminesence in the presence of $\mathrm{K}^{+}$or $\mathrm{Rb}^{+}$. The enhanced luminescence with $\mathrm{Na}^{+}$was about two times greater than that with $\mathrm{Li}^{+}$. The difference of enhanced luminescence between them was almost similar to that before the addition of cyanide.

\section{$N A D H$ oxidase in membrane fractions of $V$. harveyi}

Fig. 2 shows the effect of monovalent cation concentration on NADH oxidase activity of $V$. harveyi. It is clear that this bacterium requires $\mathrm{Na}^{+}$for maximal activity. The activity with other cations $\left(\mathrm{K}^{+}, \mathrm{Li}^{+}, \mathrm{Rb}^{+}\right)$was much smaller than with $\mathrm{Na}^{+}$. The $\mathrm{pH}$ dependency of the NADH oxidase with $0.3 \mathrm{M}$-monovalent cations is shown in Fig. 3. The optimum pH was about 7.5 to 8.0 . The NADH oxidase was very sensitive to HQNO, which is a specific inhibitor of the $\mathrm{Na}^{+}$-driven respiratory chain in $V$. alginolyticus (Tokuda \& Unemoto, 1984). Less than $1 \mu \mathrm{M}-\mathrm{HQNO}$ almost completely suppressed the NADH oxidase activity (Fig. 4). These characteristics of the NADH oxidase of $V$. harvey $i$ are quite similar to those of $V$. alginolyticus (Tokuda, 1984). 


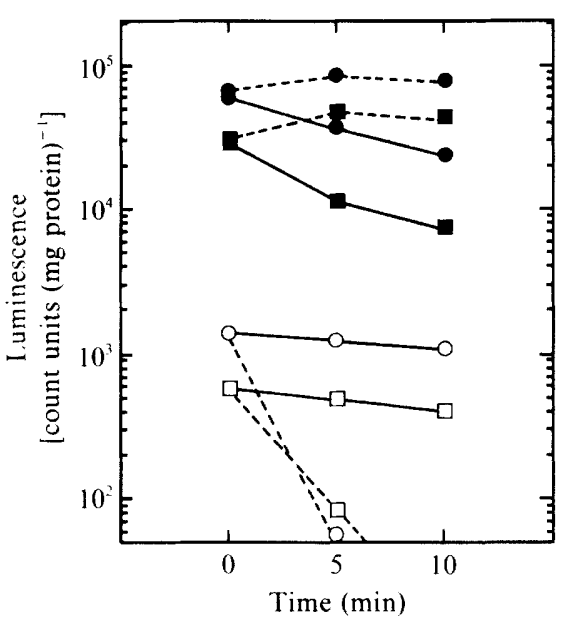

Fig. 1. Effect of $\mathrm{KCN}$ on luminescence of $V$. harveyi at $\mathrm{pH} 8 \cdot 5$. Luminescence was measured in the buffer containing $0.3 \mathrm{M}$-monovalent cation. Just after the determination of luminescence at zero time, $\mathrm{KCN}$ was added to the suspension to a final concentration of $2 \mathrm{~mm}$ (dotted line). Solid line: control (no KCN). Symbols:, $\mathrm{Li}^{+} ; \mathbf{O}, \mathrm{Na}^{+}$; $\mathrm{O}, \mathrm{K}^{+} ; \square, \mathrm{Rb}^{+}$.

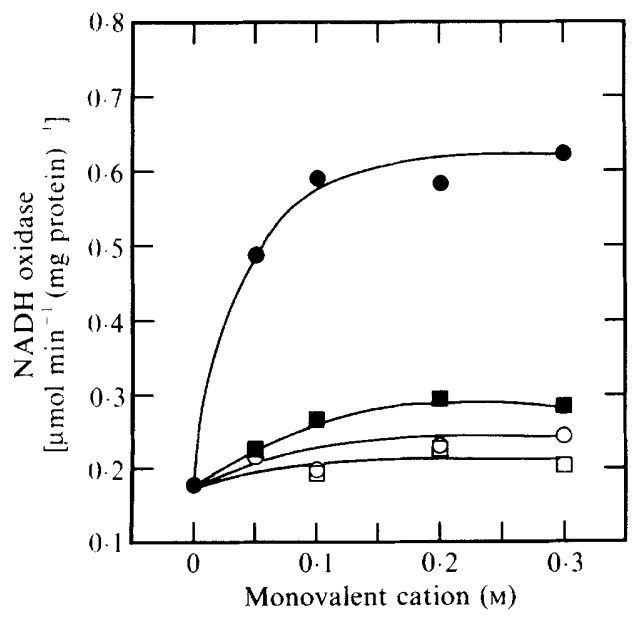

Fig. 2. Effect of monovalent cation on NADH oxidase of $V$. harveyi. $\mathrm{NADH}$ oxidase activity was measured in the assay buffer at $\mathrm{pH} 7.5$. Symbols: $\mathbf{\square},{\mathrm{I} . \mathrm{i}^{+}}^{+} \mathrm{O}, \mathrm{Na}^{+} ; \mathrm{O}, \mathrm{K}^{+} ; \square, \mathrm{Rb}^{+}$.

\section{Growth and luminescence in the presence of proton conductor}

Fig. 5 shows the growth and luminescence of $V$. harveyi in the presence of CCCP. At $\mathrm{pH} 6.5,10 \mu \mathrm{M}-\mathrm{CCCP}$ almost completely inhibited the growth (Fig. 5a), whereas at $\mathrm{pH} 8.5$, only a slight inhibitory effect was observed (Fig. 5b). Just after CCCP addition, the luminescence at $\mathrm{pH} 6.5$ started to decrease rapidly and

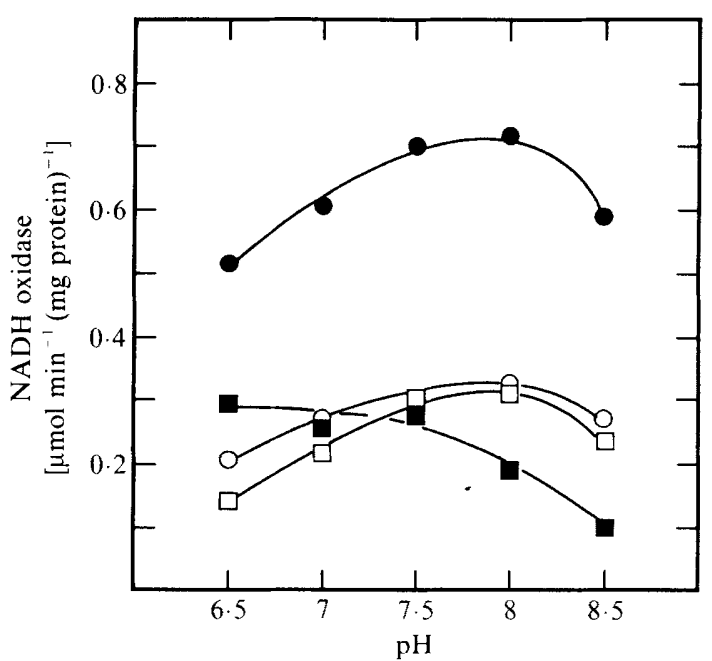

Fig. 3. Effect of $\mathrm{pH}$ on NADH oxidase of $V$. harveyi. NADH oxidase activity was measured in the assay buffer containing $0.3 \mathrm{M}$ monovalent cation. Symbols: $\square, \mathrm{Li}^{+} ; 0, \mathrm{Na}^{+} ; \mathrm{O}, \mathrm{K}^{+} ; \square, \mathrm{Rb}^{+}$.

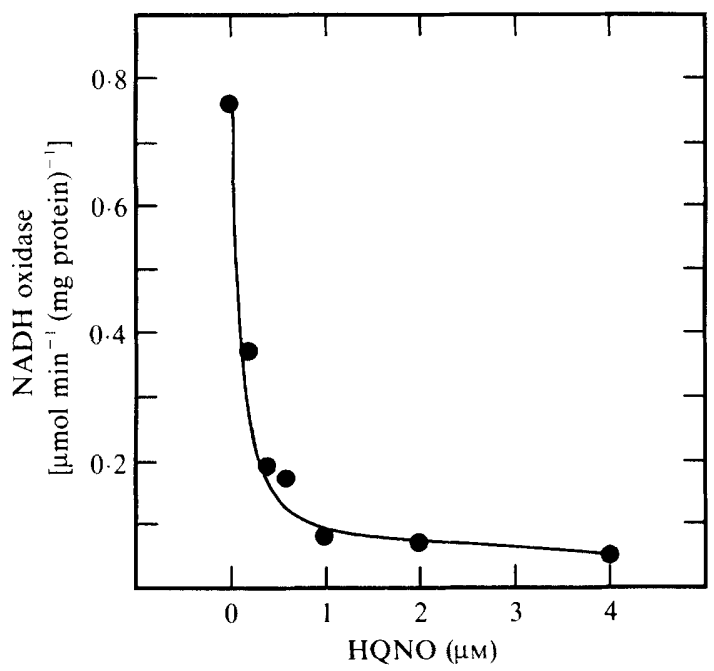

Fig. 4. Effect of HQNO on NADH oxidase of $V$. harveyi. NADH oxidase activity was measured in the assay buffer containing $0.3 \mathrm{M}-\mathrm{Na}^{+}$ at $\mathrm{pH} 7 \cdot 5$.

became undetectable within $1 \mathrm{~h}$. However, at $\mathrm{pH} 8.5$, $10 \mu \mathrm{M}$-CCCP did not inhibit luminescence.

\section{Discussion}

The oxygen uptake rate of Vibrio harveyi was influenced by the presence of monovalent cations (Table 1). The maximum oxygen uptake was observed in the presence 

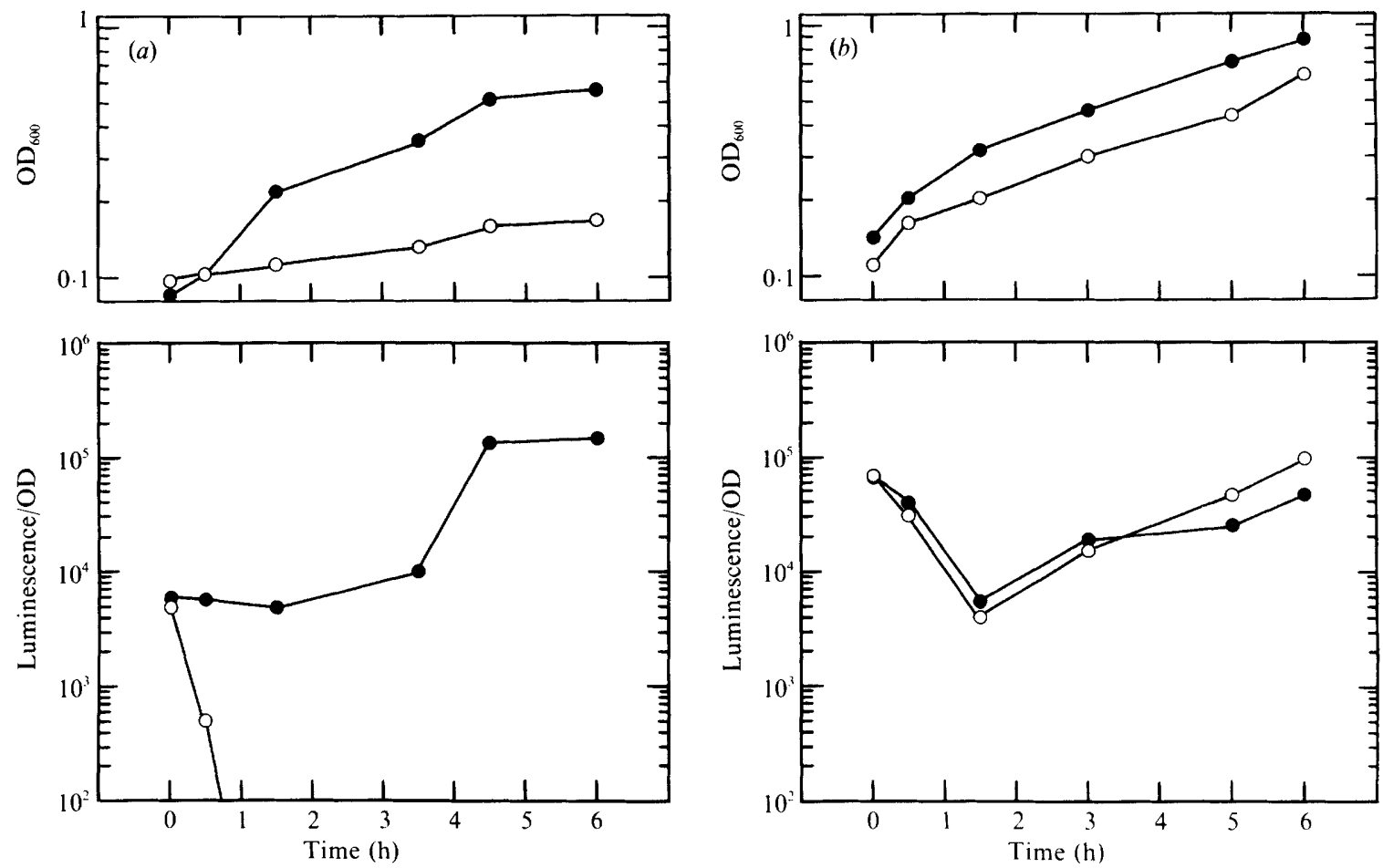

Fig. 5. Growth and luminescence of $V$. harveyi in the presence of CCCP. The medium contained either (a) $50 \mathrm{mM}-\mathrm{MES} / \mathrm{NaOH}$ (pH 6.5) or (b) $50 \mathrm{~mm}$-Tricine/ $\mathrm{NaOH}\left(\mathrm{pH} 8 \cdot 5\right.$ ). When the $\mathrm{OD}_{600}$ reached about $0 \cdot 1, \mathrm{CCCP}$ was added. Symbols: $\mathrm{O}, 10 \mathrm{mM}-\mathrm{CCCP}$ (final concentration); , control (0 mM-CCCP).

of sodium. $\mathrm{Na}^{+}$was also required for maximum luminescence at $\mathrm{pH} 8 \cdot 5$. Moreover, at alkaline $\mathrm{pH}$, the effects of other monovalent cations on luminescence and on oxygen consumption showed similar patterns (Table 1). Since the luciferase pathway would account for at most about $20 \%$ of the total oxygen uptake (Hastings \& Nealson, 1977; Makemson, 1986), we considered that the rate of oxygen consumption by the cells almost corresponds to the respiratory activity. Thus, these results indicate a cooperative relationship between the luminescent and respiratory systems.

Past experiments using respiratory inhibitors have suggested the bacterial luminescent system to be an alternative electron transport pathway that competes with the cytochrome system for both NADH and oxygen as a main electron donor and acceptor (Nealson et al., 1970; Watanabe et al., 1975; Hastings \& Nealson, 1977; Ulitzur et al., 1981; Grogan, 1984). However, the simple competitive model can not fully explain the results described above. The existence of both cooperative and competitive relations between the two systems requires an alternative explanation.

It seems possible to explain these phenomena when we hypothesize the following. (1) Luminescence and oxygen uptake rate reflect the rate of electron flow through each system i.e., changes in luminescence and oxygen uptake rate are directly caused by those in the electron transport activity in the luciferase pathway and the respiratory chain, respectively. (2) The respiratory electron flow is primarily determined by the monovalent cations. (3) Some of the electrons which flow through the respiratory system are shunted to the luciferase system. (4) All of the electron supply to luciferase occurs in connection with respiration. The results shown in Fig. 1 support our hypothesis. Although cyanide clearly increased the luminescence in the presence of $\mathrm{Na}^{+}$and $\mathrm{Li}^{+}$ions, the enhanced luminescence with $\mathrm{Na}^{+}$was still greater than that with $\mathrm{Li}^{+}$. The increase in luminescence by cyanide has been previously explained as the blockage of electron flow through cytochrome to oxygen by $\mathrm{KCN}$, which increases the electron flow rate through the luciferase system, leading to an increase in luminescence if electron supply is rate-limiting in the luciferase system. However, the above results (Fig. 1) strongly suggest that the increase in luminescence primarily depends on the respiratory activity, which is determined by the monovalent cation. In other words, an apparent increase in luminescence caused by $\mathrm{KCN}$ also depends on the 
respiratory activity. Thus it seems very reasonable to conclude that monovalent cations affect bacterial luminescence by altering respiratory activity.

However, at acidic $\mathrm{pH}$, the effects of monovalent cations on luminescence were not in accord with those on respiratory activity. It was noticeable that $\mathrm{K}^{+}$increases luminescence more than $\mathrm{Na}^{+}$. Watanabe et al. (1977) also observed the stimulatory effect of $\mathrm{K}^{+}$in Photobacterium phosphoreum. At present, the reason for the brighter luminescence with $\mathrm{K}^{+}$than with $\mathrm{Na}^{+}$at $\mathrm{pH} 6.5$ is unknown.

The requirement of $\mathrm{Na}^{+}$for maximum oxygen uptake is probably attributable to the respiratory NADH oxidase, which also required $\mathrm{Na}^{+}$for maximum activity. Figs 2 and 3 show the monovalent cation and alkaline $\mathrm{pH}$ characteristics of the NADH oxidase of $V$. harveyi. These are in good agreement with the $\mathrm{Na}^{+}$-dependent NADH oxidase of $V$. alginolyticus (Tokuda \& Unemoto, 1984). Moreover, marked sensitivity to HQNO (Fig. 4), which specifically inhibits the $\mathrm{Na}^{+}$-driven NADH : quinone oxidoreductase of $V$. alginolyticus, was also observed. These results strongly indicate that $V$. harveyi possesses a respiratory chain quite similar to that of $V$. alginolyticus. This is also supported by the growth and luminescence in the presence of CCCP (Fig. 5). Since CCCP increases the proton permeability of the cell membrane, the CCCP resistance suggests that growth, at alkaline $\mathrm{pH}$, luminescence or other cellular functions do not depend on the proton-driven respiratory system $\left(\mathrm{H}^{+}\right.$ pump), but on the sodium-driven one $\left(\mathrm{Na}^{+}\right.$pump). Similar growth patterns have also been observed in $V$. alginolyticus and other marine bacteria which possess the primary $\mathrm{Na}^{+}$pump (Tokuda \& Unemoto, 1983; Kogure \& Tokuda 1986). Although inhibition of bacterial bioluminescence by CCCP has been reported (Grogan, 1984; Guerrero \& Makemson, 1989), this is the first observation on the CCCP resistant growth and luminescence of $V$. harveyi, particularly at alkaline $\mathrm{pH}$.

We conclude that the luminescent system couples to this $\mathrm{Na}^{+}$-driven respiratory chain, particularly at alkaline $\mathrm{pH}$. This also raises the possibility that the mode of coupling between luminescent and respiratory system could change with external $\mathrm{pH}$. The correlation between luminescence and respiratory activity shown at alkaline $\mathrm{pH}$ suggests that the $\mathrm{Na}^{+}$pump may play an important role in coupling to the luciferase system.

We wish to acknowledge valuable discussions with Dr H. Tokuda, Institute of Applied Microbiology, University of Tokyo.

\section{References}

Baumann, P., Baumann, L., Woolkalis, M., \& Bang, S. (1983). Evolutionary relationships in Vibrio and Photobacterium. A basis for a natural classification. Annual Review of Microbiology 37, 369-398.

GROGAN, D. W. (1984). Interaction of respiration and luminescence in a common marine bacterium. Archives of Microbiology 137, 159-162.

Guerrero, M. A., \& MAKemson, J. C. (1989). The cytochromes of luminous bacteria and their coupling to bioluminescence. Current Microbiology 18, 67-73.

Hastings, J. W. \& Nealson, K. H. (1977). Bacterial bioluminescence. Annual Review of Microbiology 31, 549-595.

KogURE, K. \& TOKUDA, H. (1986). Membrane bioenergetics of halophilic marine bacteria. In Perspectives in Microbial Ecology: Proceedings of the Fourth International Symposium on Microbial Ecology, pp. 231-237. Ljubjana.

KogURE, K. \& TOKUDA, H. (1989). Respiration-dependent primary $\mathrm{Na}^{+}$pump in the halophilic marine bacterium, Alcaligenes strain 201. FEBS Letters 256, 147-149.

Makemson, J. C. (1986). Luciferase-dependent oxygen consumption by bioluminescent vibrios. Journal of Bacteriology 165, 461-466.

Meighen, E. A. (1988). Enzymes and genes from the lux operons of bioluminescent bacteria. Annual Review of Microbiology 42, 151176.

Meighen, E. A. (1991). Molecular biology of bacterial bioluminescence. Microbiological Reviews 55, 123-142.

Nealson, K. H. \& Hastings, J. W. (1979). Bacterial bioluminescence: its control and ecological significance. Microbiological Reviews 43, $496-518$.

Nealson, K. H., Platt, T. \& Hastings, J. W. (1970). Cellular control of the synthesis and activity of the bacterial luminescent system. Journal of Bacteriology 104, 313-322.

TokUDA, H. (1986). Sodium translocation by NADH oxidase of Vibrio alginolyticus: isolation and characterization of the sodium-pumpdefective mutants. Methods in Enzymology 125, 520-530.

ToKudA, H. \& Kogure, K. (1989). Generalized distribution and common properties of $\mathrm{Na}^{+}$-dependent $\mathrm{NADH}$ :quinone oxidoreductases in Gram-negative marine bacteria. Journal of General Microbiology 135, 703-709.

TOKUDA, H. \& UNEMOTO, T. (1981). A respiration-dependent primary sodium extrusion system functioning at alkaline $\mathrm{pH}$ in the marine bacterium Vibrio alginolyticus. Biochemical and Biophysical Research Communications 102, 265-271.

TOKudA, H. \& UNEmoTo, T. (1982). Characterization of the respiration-dependent $\mathrm{Na}^{+}$pump in the marine bacterium Vibrio alginolyticus. Journal of Biological Chemistry 257, 10007-10014.

TOKUDA, H. \& UNEmoto, T. (1983). Growth of a marine Vibrio alginolyticus and moderately halophilic $V$. costicola becomes uncoupler-resistant when the respiration-dependent $\mathrm{Na}^{+}$pump functions. Journal of Bacteriology 156, 636-643.

ToKUdA, H. \& UNEMOTo, T. (1984). $\mathrm{Na}^{+}$is translocated at NADH: quinone oxidoreductase segment in the respiratory chain of Vibrio alginolyticus. Journal of Biological Chemistry 259, 7785-7790.

Ulitzur, S., Reinhertz, A. \& Hastings, J. W. (1981). Factors affecting the cellular expression of bacterial luciferase. Archives of Microbiology 137, 159-162.

Watanabe, H., Mimura, N., Takimoto, A. \& Nakamura, T. (1975). Luminescence and respiratory activities of Photobacterium phosphoreum: Competition for cellular reducing power. Journal of Biochemistry 77, 1147-1155.

WaTANABE, H., TaKimoto, A. \& NaKamura, T. (1977). Luminescence and respiratory activities of Photobacterium phosphoreum: II. Control by monovalent cations. Journal of Biochemistry 82, 1707-1714. 